\title{
The Importance of Apple
}

\section{Rootstocks on Tree Growth, Yield, Fruit Quality, Leaf Nutrition, and} Photosynthesis with an Emphasis on 'Fuji'

Esmaeil Fallahi, ${ }^{1}$ W. Michael Colt, ${ }^{2}$ Bahar Fallahi, ${ }^{3}$ and Ik-Jo Chun ${ }^{4}$

Additional InDEX wORDs. 'Fuji', high density orchards, rootstock history, Malus domestica

Summary. Tree fruit rootstocks are used to influence precocity, tree size, fruit quality, yield efficiency, mineral uptake, and to withstand adverse environmental conditions. In this paper, we will briefly discuss the history and literature of apple (Malus domestica) rootstocks and their effects on scion tree growth, yield, fruit quality, leaf mineral nutrition, and photosynthesis. Then, the results of our long-term study on the effects of rootstocks on tree growth, yield, fruit quality and leaf mineral nutrition, and one season of photosynthesis measurement in 'BC2 Fuji' will be presented and discussed. In this study, 'Fuji' trees on 'Malling 9 NAKBAT337' (M.9) rootstock had the smallest trunk cross-sectional area (TCA), highest yield efficiency, and were the most precocious followed by those on 'East Malling-Long Ashton 26' (M.26 EMLA) and 'East Malling-Long Ashton 7' (M.7 EMLA). Trees on M.7 EMLA often had larger fruit with less color than those on M.9 and M.26 EMLA. Trees on M.7 EMLA frequently had greater leaf $\mathrm{K}$ than those on other rootstocks. Trees on M.26 EMLA always had greater leaf $\mathrm{Mg}$ than those on other rootstocks. Leaves from the current terminal shoots (CTS) of trees on M.9 had higher net photosynthesis and transpiration than those on M.7 EMLA rootstock during 1998 growing season.

Tukey (1964) and Rom and Carlson (1987) reviewed the historical background of dwarfing apples rootstocks. Apple culL ture using dwarfing trees can be traced back to 3 centuries before Christ in Persia and Asia Minor. From Persia, Alexander the Great sent a dwarf apple tree to the Lyceum, a center of learning created by Aristotle. Theophrastus, who was a student of Aristotle and directed the Lyceum, mentions that the dwarf apple trees had long been grown in Persia and Asia Minor. The word pardis in the Persian language means heaven, and the apple was believed to be a fruit from heaven. Pardis (Sanskrit paradeca) also means orchard or garden in Persian.

\footnotetext{
Authors wish to express their appreciation to the Idaho Apple Commission and Washington State Tree Fruit Research Commission for their financial support of this project.

${ }^{1}$ Professor of pomology and corresponding author, Department of Plant, Soil, and Entomological Sciences, Parma Research and Extension Ctr., University of Idaho, 29603 U of I Lane, Parma, Idaho, 83660.

${ }^{2}$ Associate professor, Extension Horticulturist, University of Idaho.

${ }^{3}$ Research assistant of pomology, University of Idaho.

${ }^{4}$ Postdoctoral fellow, University of Idaho.
} 
Pardis is a dwarfing, low-growing and self-rooting apple. Use of dwarf horses and dwarf trees were popular in Persia, and this it reflected in the hieroglyphics of Persepolis, the palace of Achaemenian and other documents and monuments of Sassanians, Parthians and Safavids dynasties. This Persian word in English is paradise. By the mid-15th century, use of dwarfing apple rootstocks for training trees in different shapes and forms in gardens became more common. At that time, two groups of rootstocks were recorded: one was 'French Paradise', which was very dwarf, and the less dwarfing rootstock called 'Doucin' or 'English Paradise'. In 1912, researchers at the East Malling Research in Kent, England began to gather rootstocks named 'Paradise' and 'Doucin' from around the world. Between 1912 and 1918, clonal Malling (M) rootstocks were classified and described in East Malling. In 1920, East Malling and Merton Stations collaborated and hybridized the 'Northern Spy' and Malling rootstocks and created Malling-Merton (MM) rootstocks.

Dwarfing rootstocks were imported to the United States from Europe in the early 1800s. Interest in using dwarfing rootstocks for apple trees in the United States had several cycles, and each cycle had a different reason (Tukey, 1964). In early 1880s, these rootstocks were used only for ornamental or home gardening purposes. Between 1835 and 1860, there was an increased interest in dwarfing fruit trees in America. This interest declined between 1860 and 1890 because of heavy fruit production, resulting in low prices. In 1890, the interest in the use of dwarfing trees increased again because of the need to control san jose scale (Aspidiotus perniciosus) by fumigating with hydrogen cyanide gas, and smaller trees were easier to fumigate. After the introduction of lime sulfur and oil spray to control the San Jose scale between 1907 and 1910, the interest in dwarf apple trees ceased almost as quickly as it had begun. Hall (1915) summarized the work of U.P. Hedrick and concluded that dwarf apple trees were not commercially viable. By 1920, use of dwarfing rootstock was virtually discredited. In 1920 , Malling rootstocks were tested in New York, Pennsylvania and Massachusetts for the first time in the U.S. In 1943, the 'Oregon Apple Rootstock' (OAR 1) was introduced. In 1953, CornellGeneva (CG) rootstocks were developed from the open pollination of dwarfing M.8 rootstock with M.1 to M.16 of the Malling series in Geneva, N.Y. Other groups of rootstocks such as the Polish series $(\mathrm{P})$ in Poland in 1954, the Ottawa series $(\mathrm{O})$ in Canada in 1961, the Budagovsky series (B or Bud.) in 1976, and the Michigan series (MAC) in the U.S. in 1980 were developed later. The conclusion of Hall (1915) was later refuted by many other researchers (Kelsall, 1946; Regional Rootstock Research Project (NC-140), 1991; Norton, 1970). Today, most of the existing apple orchards in the United States and other apple-growing regions of the world are planted on the clonal rootstocks.

\section{Growth, yield, and fruit quality of traditional apple cultivars}

Dwarfing rootstocks are widely used in the apple industry in the U.S. and other parts of the world. Interstems have been tested to control tree size and to avoid the need for tree support, but have not gained wide acceptance. In the recent years, tree growth and productivity of 'Delicious' apple trees on many dwarfing rootstocks have been evaluated within the scope of national program, NC-140 (1990, 1991, 1996) in the United States. Autio and Southwick(1986) studied tree growth, yield, and anchorage of 'Starkrimson Delicious' and 'Gardiner Delicious' apple trees on M.26, MM.111, M.7A rootstocks and M.9/M.111 and M.9/ MM.106. They found that trees on MM.111 were the largest, least productive (per tree basis), least efficient, and produced the lowest amount of yield per area. Trees on this rootstock, however, had better anchorage than any other rootstock or rootstockinterstem combination (Autio and Southwick, 1986). Ferree (1992) compared performance of 'Smoothee Golden Delicious' apple on two rootstocks and four dwarfing interstems over 10 years. He reported that trees on M.7 had the largest canopy volume and truck cross-sectional area and lowest cumulative yield per hectare. Trees on MM.l1l with an interstem of M.27 were smaller than trees with an interstem of M.9 (Ferree, 1992). Autio and Southwick (1993) evaluated the performance of 'Rogers Red McIntosh' and 'Macspur' apples on M.7A, M.26, M.9, and M.9/ MM.111 rootstocks. In their study, trees on M.7A were the largest in size after 10 years. Those on M.26 and M.9/MM.111 were similar in size and trees on M.9 were the smallest. Trees on M.9 were the most precocious, yield efficient, with greatest fruit set in the third and fourth growing seasons. Autio and Southwick (1993) also reported that trees on M.7A had their highest yield through the tenth season, followed by those on M.26. Meheriuk et al. (1994) assessed the effects of four rootstocks and reported that tree canopies on M.9 EMLA and 'Ottawa 3' were smaller and were more yield efficient than canopies on M.26 or M.4.

Drake et al. (1988) reported that fruit maturity of 'Goldspur Golden Delicious' apples on MM.111 was delayed compared to fruit on M.26 or seedling rootstocks. Fallahi et al. (1985a, 1985b) observed a delay in ripening of 'Starkspur Golden Delicious' apple on OAR 1 compared to fruit on seedling, MM.111, MM.106, M.7, and M.26 rootstocks. Autio et al. (1991) reported a tendency for M.27 to advance maturity in 'Starkspur Supreme Delicious' and for OAR 1 to delay maturity in this cultivar. They also found a slight advancement in maturity of 'McIntosh' on 'Ottawa 3' compared to M.26, M.7 EMLA, or M.7 A. Meheriuk et al. (1994) found small or no difference among rootstocks for the scion fruit internal ethylene, soluble solids, skin color, firmness, and average fruit weight. Ferree (1992) reported that rootstock and interstems had very little effect on fruit size of 'Smoothee Golden Delicious' apple.

Autio and Southwick (1993) experimenting with three rootstocks and M9/MM.111, found that 'McIntosh' fruit from trees on M.9/MM.111 had the most surface red color, while trees on M.7 A had the least red color. In that report, fruits from trees on M.9 and M.26 had similar skin color. Fruit weight was greatest for trees on M.9 rootstock (Autio and Southwick, 1993).

\section{Leaf mineral nutrition of traditional apple cultivars}

The effect of rootstocks on nutrient requirement is related directly to 
the influence of rootstock on tree size, specifically the amount of structural wood in trunks, large limbs, and roots (Stiles, 1994). Jones (1971) showed that xylem sap collected from various apple rootstocks contained different concentrations of minerals suggesting that major genetic variation may exist in rootstocks with respect to their ability for uptake and translocation of minerals from the soil. Tukey et al. (1962) observed significant differences in the scion leaf nutrient content depending upon the rootstock, the scion varieties and the orchard location. However, these differences were not always consistent. They observed that leaves of 'Jonathan' on various East Malling rootstocks (M.1, M.2, M.7, M.13) showed significant differences in $\mathrm{N}, \mathrm{P}$, and $\mathrm{Mg}$ but not in $\mathrm{K}$ or $\mathrm{Ca}$, while leaves of 'Rome Beauty' in combination with the same rootstocks showed significant differences in all nutrients tested including $\mathrm{K}$ and $\mathrm{Ca}$. They also reported significantly higher $\mathrm{K}$ in the leaves of 'Rome Beauty' on M.I than on seedlings. In addition to the differences among rootstocks, interstocks had significant influences on scion leaf mineral composition.

Sistrunk and Campbell (1966) found higher Ca concentrations in the leaves of 'Winesap', 'Rome' and 'Jonathan' apple cultivars on hibernal (Malus sp.) compared to those on french crab apple ( $M$. pumila $\times M$. baccata). They also noted that soil applications of lime and foliar sprays of calcium nitrate and calcium acetate resulted in higher $\mathrm{Ca}$ accumulation in the leaves of all tested cultivars on hibernal rootstock but had no effect on the leaves of these cultivars on french crab apple.

Lockard (1976), in a greenhouse experiment with 'Red Delicious' on MM.111, MM.106, and M.9 rootstocks with and without 'Red Delicious', MM.106, or M.9 interstems reported that rootstock treatments differentially affected the leaf levels of $\mathrm{N}$ and $\mathrm{Ca}$ over a 4 -year period. However, he did not observe differential effects of rootstocks on scion leaf $\mathrm{Mg}$ concentration as found by Hoblyn (1940-41) and Awad and Kenworthy (1963). However, M.7, which was considered as the most susceptible to $\mathrm{Mg}$ deficiency in other reports (Awad and Kenworthy, 1963; Hoblyn, 1940-41), was not included in Lockard's experiment. Lockard
(1976) noted that leaf Ca of trees on MM.111 was lower than those on MM.106 or M.9 rootstocks. Lockard (1976) also reported that the level of $\mathrm{K}$ in the scion leaves was lower with M.9 than with MM.106 rootstocks or with 'Red Delicious' interstock.

Whitfield (1963) reported significantly higher Ca but lower $\mathrm{K}$ and $\mathrm{P}$ in the leaves of 'Jonathan' than those of 'Cox's Orange Pippin.' Leaves of trees on M.9 rootstock had higher $\mathrm{Ca}$ and $\mathrm{Mg}$ than those on M.7, and trees on M.2 showed higher $\mathrm{P}, \mathrm{Ca}$, and $\mathrm{Mg}$ values than those on M.16. Whitefield has also reported (1963) very low leaf $\mathrm{Mg}$ concentration on M.7 rootstock. On the other hand, Dzamic et al. (1980) did not report any significant differences in 'Golden Delicious' leaf mineral content in relation to rootstock [(M.4, M.7, seedling of european apple (Malus sylvestris)] vigor.

Eaton and Robinson (1977) used four cultivars of apples as scions with 16 combinations of interstocks. They reported higher leaf accumulations of $\mathrm{P}$ and $\mathrm{Fe}$ in 'Delicious' apples than those in the leaves of 'Golden Delicious', 'McIntosh', or 'Spartan.' However, they concluded that interstock did not influence the scion leaf mineral concentrations.

Bould and Campbell (1970) studied three apple rootstocks (MM.104, MM.111, MM.106) infected with four different viruses. They reported that the viruses reduced scion leaf $\mathrm{N}$ more on MM.111 than the other rootstocks. In the presence of viruses, trees on MM.106 had higher leaf Mg and Ca than on other rootstocks.

Fallahi et al. (1984), experimenting with 'Starkspur Golden Delicious' apple on M.1, M.7, MM.106, seedlings, M.26, and OAR 1 reported that scion leaves on OAR 1 had lower $\mathrm{Ca}$ than on M.7, MM.106, and M.1 and lower $\mathrm{Mg}$ than on M.26. In that report, scion leaves on M.26 had the highest levels of $\mathrm{Mg}$ compared to the scion leaves on other tested rootstocks under climatic conditions of western Oregon. Higher leaf Mg in some other apple cultivars on $M .26$ rootstocks was later confirmed in several additional locations (Fallahi and Simons, 1993a; Fallahi et al., 1998; Fallahi and Mohan, 2000; Rom et al., 1991).

In general, rootstock can influence leaf mineral concentrations and fruit quality. Vigor of rootstock and crop load of the scion cultivar also plays a major role on uptake and translocation of minerals. We will discuss the effects of crop load on mineral uptake and year to year variations later in this paper. In some minerals, including $\mathrm{Ca}$, concentrations of fruit rather than leaf tissue, can have a major impact on fruit quality.

\section{Influence of rootstock on traditional apple photosynthesis}

Several researchers have shown that scion CTS leaves of trees on more vigorous rootstocks have higher net photosynthesis (Pn) than those on dwarfing rootstocks. Ferree and Barden (1971) found that CTS leaf Pn of apple trees grown on seedling rootstocks was higher than that on MM.106. Schechter et al. (1991) reported that trees grown on vigorous rootstocks had higher CTS leaf Pn rates than those on dwarfing rootstocks. Baugher et al. (1994) indicated that CTS leaf Pn of 'Golden Delicious' apple trees was higher on M.7 EMLA or MM.111 EMLA than that on M.9 EMLA rootstock. However, Barden and Ferree (1979) reported that the Pn and dark respiration of container grown 'Delicious' trees were unaffected by rootstocks.

\section{Previous research with rootstocks for 'Fuji' apple}

'Fuji' was first introduced in Japan in 1958 as a cross of 'Ralls Janet' and 'Red Delicious' apples. Consequently, most of the early 'Fuji' research was conducted in Japan. Tsuchiya et al. (1974) reported that 'Fuji', 'Golden Delicious', and 'Starking Delicious' apple trees on M.9 had smaller TCA and canopy volume than those on plum-leaved apple (Malus prunifolia) 'Ralls Seedling' 12 years after planting. Trees on M.9 were more precocious and had greater yield efficiency than those on other rootstocks. Average fruit weight from trees on M.9 was less than those from 'Ralls Seedling'. 'Fuji' fruit were firmer when grown on M.9 than on other rootstocks. In a different study, Tsuchiya et al. (1976) reported that 'Fuji' on M.26 had a greater cumulative yield than those on M.4, MM.104, MM.106, or MM.111. In their report, 'Fuji' trees on M.26 had larger fruit than those on MM.106.

Nagai and Ishii (1979) reported 
that 'Fuji' leaves had significantly greater $\mathrm{N}, \mathrm{P}, \mathrm{K}, \mathrm{Ca}, \mathrm{Mg}, \mathrm{Fe}$, and $\mathrm{Mn}$ than 'Golden Delicious' leaves and that trees on M.9 had similar levels of leaf $\mathrm{N}, \mathrm{K}, \mathrm{Mg}$, and $\mathrm{Mn}$, but less leaf $\mathrm{P}$ and greater leaf $\mathrm{Ca}$ and $\mathrm{Fe}$ than trees on M.7. Fallahi et al. (2001) reported that leaves of 'BC-2 Fuji' trees on M.7 EMLA had significantly higher concentrations of $\mathrm{K}$ and $\mathrm{Cu}$ than those on 'Ottawa 3' and Bud.9. In that study, leaves of trees on Bud.9 had higher $\mathrm{Ca}$ than those on M.7 EMLA.

Effects of rootstock on 'BC-2 Fuji' apple photosynthesis were first reported by Fallahi et al. (2001) and Chun et al. (2001). In these studies, 'Fuji' on Bud.9 had lower CTS leaf Pn, while those on 'Ottawa 3' had higher CTS leaf Pn over two growing seasons. In that study, fruits from trees on 'Ottawa 3' often had higher SSC and authors suggested that higher SSC could be related to the higher CTS leaf Pn of trees on this rootstock.

\section{Experiment with rootstocks for 'Fuji' at the University of Idaho}

INTRODUCTION, MATERIALS, AND METHODS. 'Fuji' is an important new apple cultivar in the U.S., and was introduced to the Pacific northwestern U.S. in the 1980s. In spite of the increasing popularity of 'Fuji' in the marketplace, there is limited information concerning the impact of rootstocks on the nutrition and fruit quality of this cultivar. Consequently, in 1991, we started a long-term experiment at the University of Idaho Parma Research and Extension Center to study the effects of rootstocks and various nitrogen regimes on tree growth, fruit quality and mineral nutrition of 'BC-2 Fuji' apple over several growing seasons.

The experimental orchard was located near Parma, Idaho. The orchard site was not cultivated previously and had a uniform soil profile. The soil type was a sandy loam with a $\mathrm{pH}$ of about 7.5. The ground was plowed down to about 24 inches (61 $\mathrm{cm}$ ) before planting. Soil samples indicated that no harmful nematodes were present. Uniform size $[1.27 \mathrm{~cm}(0.5$ inches) trunk diameter] 'BC-2 Red Fuji' apples on M.9, M.26 EMLA, or M.7 EMLA were obtained from C \& O Nursery, Inc. (Wenatchee, Wash.) and planted at $2.7 \times 5.5 \mathrm{~m}(9 \times 18 \mathrm{ft})$ spacing on 4 Apr. 1991. A microjet sprinkler system was installed with one riser per tree, located midway between two adjacent trees in a row. The orchard was irrigated based on monitoring soil moisture with water sensors.

A trellis system was installed and bamboo poles were used to support trees. Trees were topped at $71 \mathrm{~cm}(28$ inches) from the ground after planting. The central leader was bent in June every year in a zig-zag pattern. Any branch competing with the main leader was removed. Lateral branches were bent with strings and fastened to the main trunk at about $55^{\circ}$ angle from vertical to induce flower bud initiation.

Zinc-50 [a $\mathrm{Zn}$-zinc-containing compound with $50 \% \mathrm{Zn}$ ] was sprayed in the late dormant season (late March) every year at a concentration of about $3.1 \mathrm{~g} \cdot \mathrm{L}^{-1}(0.4 \mathrm{loz} / \mathrm{gal})$ to runoff. Other cultural practices in this experimental orchard were similar to those used in commercial apple orchards.

Since the soil was low in N, $48 \mathrm{~g}$ ( $1.7 \mathrm{oz}$ ) of actual $\mathrm{N}$ per tree (as urea) was applied to all trees in a $0.6 \mathrm{~m}(2 \mathrm{ft})$ radius around the trunk on 10 July 1991 (about 3 months after planting). Experimental $\mathrm{N}$ treatments started in 1992. Five quantities of $\mathrm{N}$ as urea $(46 \%$ actual $\mathrm{N})$ were applied to the ground at the base of each tree in a circle with radius of about $0.76 \mathrm{~m}(2.5$ $\mathrm{ft}$ ) (in 1992-93) and $0.91 \mathrm{~m}(3.0 \mathrm{ft})$ (in 1994-98) from the trunk of the trees. The experiment was arranged according to a randomized-completeblock split-split plot design with rootstocks as main plots and five levels of ground applied $\mathrm{N}$ as subplots, and two times of application (spring or fall) as subsub plots with four two-tree plots per replication (block) with four replications (blocks). Therefore, a total of eight trees per treatment for the smallest experimental unit were used. For spring applications, each level of the five quantities of $\mathrm{N}$ was split in half. One half was applied at full bloom and the second half was applied around 15 June. In 1992, 27.2, 77.1, 127.0, 176.9, or $226.8 \mathrm{~g}(0.96,2.72,4.48$, 6.24 , or $8 \mathrm{oz}$ ) actual $\mathrm{N}$ per tree in each year was applied. In 1993 through $1998,31.8,99.8,167.8,235.9$, or $303.9 \mathrm{~g}(1.12,3.52,5.92,8.32$, or $10.72 \mathrm{oz}$ ) of actual $\mathrm{N}$ per tree per year was applied. For fall application, all $\mathrm{N}$ was applied in early October of each year. Trees were watered after spring and fall applications.
Thirty-four fruit from each tree were picked randomly at the commercial harvest time (between 17 and 20 Oct.) in 1993 through 1998. Fruit were weighed, placed in perforated polyethylene bags and tested for various quality attributes at harvest. Fruit color was rated visually at harvest and after storage on a scale of $1=20 \%$ of fruit surface area pinkish-red progressively to $5=100 \%$ of fruit surface area pinkish-red. Fruit firmness was measured on three peeled sides of each fruit by a penetrometer (Facchini, Alfonsine, Italy). These fruits then were cut equatorially. One wedge from the calyx-end half of every fruit was juiced, and the soluble solids concentration (SSC) was measured by placing three to four drops of juice on a hand held, temperature-compensated refractometer (Atago Nl, Tokyo, Japan). The stem-end half of the fruit at harvest was dipped iodine solution and the starch degradation pattern (SDP) for each fruit was recorded by comparison with the SDP standard chart developed for apple by Bartram et al. (1993). Using this procedure, we considered very immature fruit to have SDP of 1.2 and very mature fruit to have SDP of 6.0.

Thirty leaves per tree were sampled randomly from the middle of the current-season's shoot in mid-August 1992 through 1998. Leaves were washed in a mild Liqui-nox detergent solution (Alconox Inc., New York), rinsed with distilled water, and dried in a forced-air oven at $65^{\circ} \mathrm{C}\left(149^{\circ} \mathrm{F}\right)$. Leaves were weighed before and after drying, and percent dry weight was calculated. Dried leaf tissue was ground to pass a 40 -mesh screen, and analyzed for $\mathrm{N}$ by the micro-Kjeldahl method (Schuman et al., 1973) and for K, Ca, $\mathrm{Mg}, \mathrm{Fe}, \mathrm{Zn}, \mathrm{Mn}$, and $\mathrm{Cu}$ by dry ashing at $500{ }^{\circ} \mathrm{C}\left(932{ }^{\circ} \mathrm{F}\right)$, digestion, and atomic absorption spectrophotometer (Perkin-Elmer Bl100, Norwalk, Conn.) as described by Chaplin and Dixon (1974) and Jones (1977).

Photosynthesis rates and transpiration of current terminal shoot (CTS) and spur leaves of the scion on M.9 and M.7 EMLA were measured in mid-June, mid-July, and mid-August 1998, using a portable photosynthesis system (LI-6200, LI-COR, Lincoln, Nebr.).

Analyses of variance were conducted by SAS (SAS Institute, Cary, N.C.), and means were compared by least significant difference (LSD) at 0.05 . 
Table 1. The effect of 'Malling 9 NAKBAT337' (M.9), 'East Malling-Long Ashton 26' (M.26 EMLA), and 'East Malling-Long Ashton 7' (M.7 EMLA) rootstocks on tree growth in 'BC-2 Fuji' appleover several years. ${ }^{\mathrm{z}}$

\begin{tabular}{lcccc}
\hline & \multicolumn{4}{c}{ Trunk cross-sectional area $\left(\mathbf{c m}^{2}\right)^{\mathrm{y}}$} \\
\cline { 2 - 5 } Rootstock & $\mathbf{1 9 9 2}$ & $\mathbf{1 9 9 3}$ & $\mathbf{1 9 9 4}$ & Difference 1994-92 \\
\hline M.9 & $2.85 \mathrm{c}$ & $5.85 \mathrm{c}$ & $14.78 \mathrm{c}$ & $12.00 \mathrm{c}$ \\
M.26 EMLA & $3.20 \mathrm{~b}$ & $6.92 \mathrm{~b}$ & $19.69 \mathrm{~b}$ & $16.79 \mathrm{~b}$ \\
M.7 EMLA & $3.71 \mathrm{a}$ & $8.35 \mathrm{c}$ & $24.22 \mathrm{a}$ & $20.51 \mathrm{a}$ \\
\hline
\end{tabular}

${ }^{\mathrm{z}}$ Mean separated with columns by LSD at 0.05 .

$\mathrm{y} 1.00 \mathrm{~cm}^{2}=0.155 \mathrm{inch}^{2}$

Only rootstock main effects are reported in this paper.

Results and discussion. 'Fuji' trees on M.9 rootstock had the smallest TCA, followed by those on M.26 EMLA and M.7 EMLA (Table 1). Trees on M.9 were more precocious, followed by those on M.26 EMLA and M.7 EMLA. Trees on M.9 had a few fruit in 1992 (data not shown). Trees on both M.9 and M.26 EMLA had small yields in 1993, while trees on M.7 EMLA did not produce any fruit (data not shown). Trees on M.9 or M.26 EMLA had greater yield per tree and yield efficiency in 1994 than those on M.7 EMLA (Table 2). Precocity, high yield efficiency, and smaller size of trees on M.9 rootstock is in agreement with previous reports on 'Fuji' (Tsuchiya et al., 1974) and on 'Rogers Red McIntosh' and 'Macspur' (Autio and Southwick, 1993). These desir- able characteristics make M.9 a popular rootstock for high-density planting systems. However, trees on this rootstock are prone to rodent damage and adverse environmental conditions. Yield in trees on all rootstocks were similar in 1995 (Table 2). From 1996 on, trees on M.7 EMLA had greater yield per tree than those on M.9 and M.26 EMLA (Table 2). Also, trees on M.9 have less foliage, leading to significantly more sunburn on fruit than other rootstocks, particularly in 1994 when temperatures exceeded $38{ }^{\circ} \mathrm{C}$ $\left(100.4^{\circ} \mathrm{F}\right)$ during several days in summer (data not shown).

Trees on M.7 EMLA often had larger fruit with less color than those on M.9 and M.26 EMLA, although differences were not always statistically significant (Table 2). Fruits from trees on M.26 EMLA rootstock with $99.8 \mathrm{~g}$ actual $\mathrm{N}$ per tree often had a color rating of less than 3 in 1994 through 1996. This suggests that $99.8 \mathrm{~g} \mathrm{~N}$ per tree is excessive for 'Fuji' on M.26 EMLA (data not shown). Fruit from trees on M.7 EMLA always had lower SDP at harvest than those on other rootstocks (Table 2). Firmness of fruit from trees on M.9 and M.7 EMLA was similar during 1994, 1995 and 1996; however, fruit from trees on M.7 EMLA had significantly lower firmness than those on M.9 in 1997 and 1998. Fruit from trees on M.26 EMLA had lower SSC than those on M.9 rootstock 3 out of 5 years (Table 2 ).

Leaf percent dry weight was not affected by rootstock (data not shown). No consistent trend was found in leaf N between trees on different rootstocks (Table 3). Trees on M.26 EMLA always had greater leaf $\mathrm{Mg}$ than those on other rootstocks (Table 3 ), which is in agreement with previous observations (Fallahi et al., 1984, 1993b, 1998; Fallahi and Mohan, 2000; Rom et al., 1991). Trees on M.7 EMLA often had lower leaf $\mathrm{Mn}$ than those on other rootstocks (Table 3 ).

Trees on M.7 EMLA often had greater leaf $\mathrm{K}$ than those on other rootstocks between 1993 through 1996 (Table 3). Higher leaf $\mathrm{K}$ in trees on M.7 EMLA could be due to the lower production of these trees in the early years of the experiment. When

Table 2. The effect of 'Malling 9 NAKBAT337’ (M.9), 'EastMalling-LongAshton 26’' (M.26 EMLA), and 'EastMalling-Long Ashton 7' (M.7 EMLA) rootstocks on yield efficiency, yield, and fruit quality at harvest time in 'BC-2 Fuji' apple over several years. ${ }^{\mathrm{Z}}$

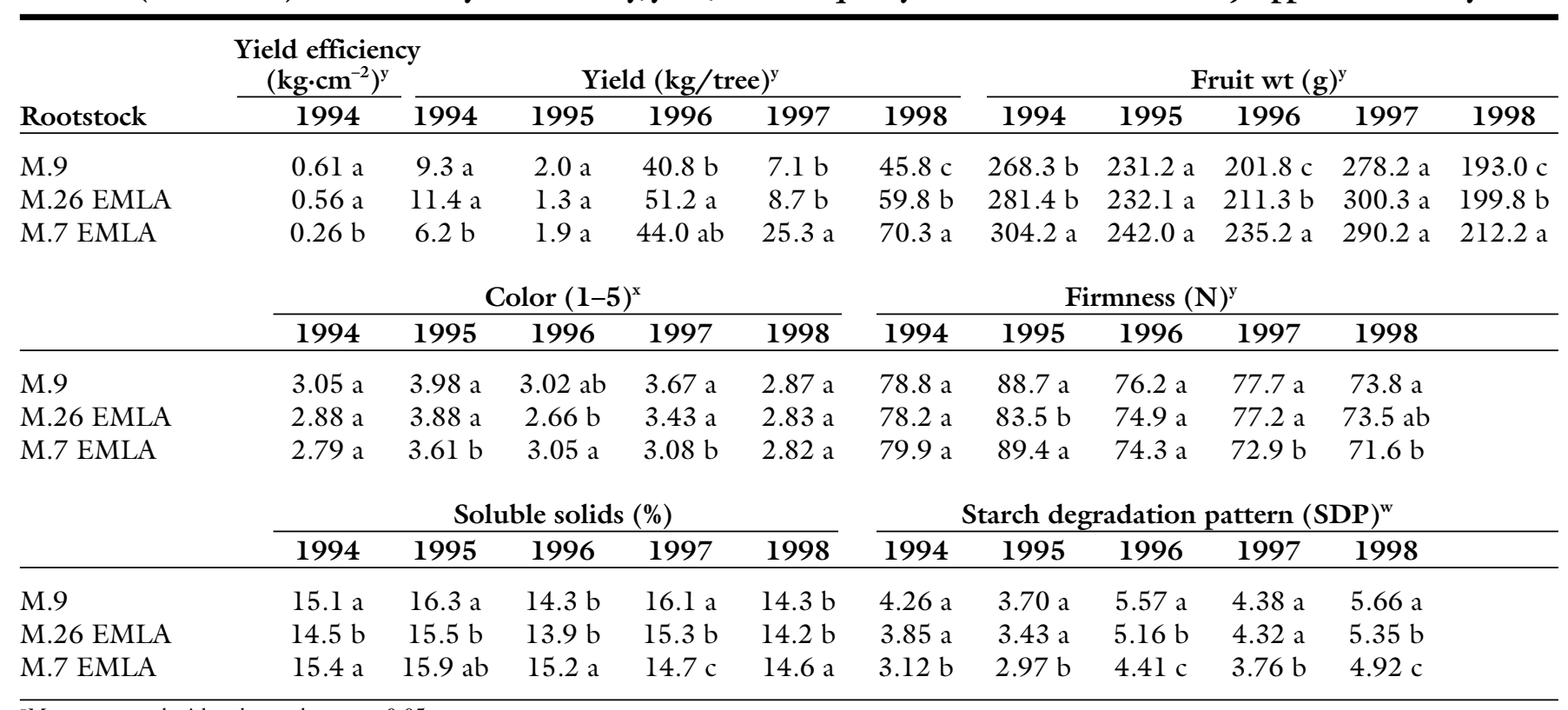

${ }^{\mathrm{z}}$ Mean separated with columns by LSD at 0.05 .

y $1.00 \mathrm{~cm}^{2}=0.155$ inch $^{2}$

$1.00 \mathrm{~kg} \cdot \mathrm{cm}^{-2}=14.223 \mathrm{lb} /$ inch $^{2} ; 1.0 \mathrm{~kg}=2.2 \mathrm{lb} ; 100.0 \mathrm{~g}=3.53 \mathrm{oz} ; 1.0 \mathrm{~N}=0.225 \mathrm{lb}$ force.

${ }^{\mathrm{x}}$ Color rating: $\mathrm{l}=$ green progressively to $5=$ uniformly red.

wSDP: least $\mathrm{SDP}=1.2 ;$ highest $\mathrm{SDP}=6.0$. 
Table 3. The effect of of'Malling 9 NAKBAT337' (M.9), 'EastMalling-Long Ashton 26' (M.26 EMLA), and 'East Malling-Long Ashton 7' (M.7 EMLA) rootstocks on leaf mineral of'BC-2 Fuji' apple over several years. ${ }^{\mathrm{z}}$

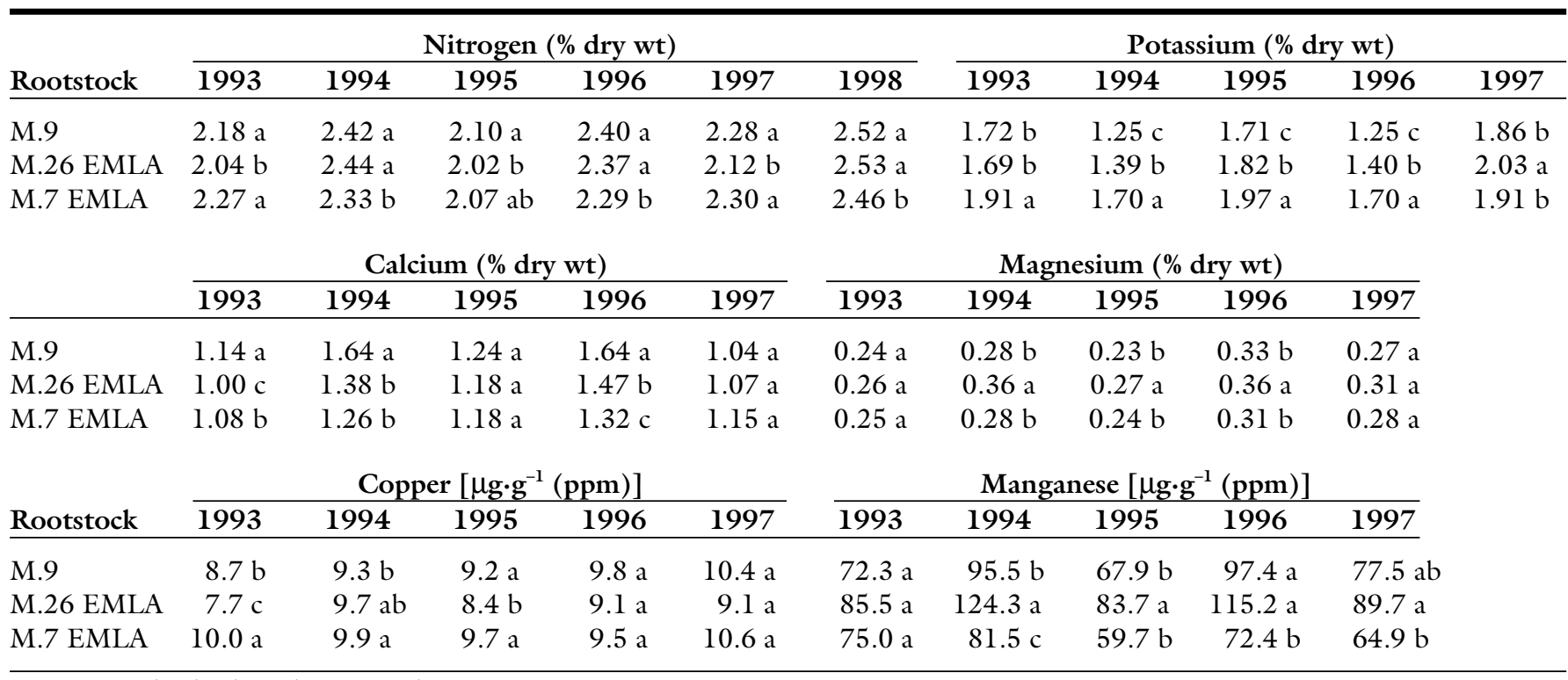

${ }^{\mathrm{z}}$ Mean separated with columns by LSD at 0.05 .

Table 4. Effects of 'Malling9NAKBAT337’ (M.9) and 'EastMalling-LongAshton 7’ (M.7 EMLA) rootstocks on photosynthesis and transpiration of 'BC-2 Fuji' during 1998 growing season.

\begin{tabular}{|c|c|c|c|c|c|c|}
\hline Rootstock & \multicolumn{3}{|c|}{ Photosynthesis $\left(\mu \mathrm{mol} \cdot \mathrm{m}^{-2} \cdot \mathrm{s}^{-1}\right)$} & \multicolumn{3}{|c|}{ Transpiration $\left(\mathrm{mol} \cdot \mathrm{m}^{-2} \cdot \mathrm{s}^{-1}\right)$} \\
\hline M.9 & $13.67 \mathrm{a}$ & $9.22 \mathrm{a}$ & $8.54 \mathrm{a}$ & $3.36 \mathrm{a}$ & $3.52 \mathrm{a}$ & $3.38 \mathrm{a}$ \\
\hline
\end{tabular}

${ }^{\mathrm{z}}$ Mean separated with columns by LSD at 0.05 .

trees do not produce to their full capacity, less $\mathrm{K}$ is partitioned or translocated into the fruits, resulting in greater leaf $\mathrm{K}$. This situation changed in 1997 when trees on M.7 EMLA rootstock gradually reached their full production (Tables 2 and 3). Lower crop loads have also been shown to increase leaf $\mathrm{K}$ due to a decreased demand by fruit in 'Delicious' apple trees (Fallahi and Simons, 1993a, 1993b).

We found considerable year-toyear variations in 'Fuji' leaf minerals on a given rootstock due to crop load effects. The higher concentration of leaf Kin the trees on M.7 EMLA trees, as discussed earlier, is a good example for year-to-year variation of leaf minerals as a result of crop load changes. Several researchers have found yearto-year variation in the mineral compositions of apple leaves (Eaton and Robinson, 1977; Kennedy et al., 1980). Kennedy et al. (1980) noted that year-to-year differences in leaf $\mathrm{N}$ and $\mathrm{P}$ concentrations were greater than the rootstock differences, whereas significant influences of rootstocks were seen for leaf $\mathrm{K}, \mathrm{Mg}$, and $\mathrm{Ca}$. Whitfield
(1963) suggested that fertilizer requirements vary due to season and rootstock. Rom et al. (1991), studied concentrations of leaf minerals of 'Starkspur Supreme Delicious' apple as influenced by rootstock, location, and year-to-year variations over several growing seasons. They found that effects of rootstock on scion leaf minerals were small. However, under low soil $\mathrm{pH}$ conditions of Arkansas, trees on M.27 EMLA and MAC.9 showed high Mn and expressed Mn toxicity. In that study, rootstock was a significant source of variation for leaf $\mathrm{K}, \mathrm{Ca}$, and $\mathrm{Mg}$, but not N. Soil variability caused significant differences in $\mathrm{N}, \mathrm{K}$, and $\mathrm{Mg}$ and accounted for $63 \%$ and $43 \%$ of variation in leaf $\mathrm{N}$ and $\mathrm{Mg}$, respectively. Rom et al. (1991) also reported that year-to-year variation was an important source of variation for leaf $\mathrm{N}$, $\mathrm{K}, \mathrm{Ca}$, and $\mathrm{Mg}$, and accounted for the greatest variation of $\mathrm{K}(44 \%)$ and Ca (51\%).

Net photosynthesis of CTS leaves between June and August in 1998 decreased as the growing season progressed (Table 4). Trees on M.9 al- ways had higher carbon dioxide assimilation (photosynthesis) and transpiration during the 1998 growing season. These differences could be due to the smaller canopy size of trees on M.9, therefore, allowing more light penetration through the canopy.

The challenge for the future is to define nutrient levels as they are influenced by crop load. This process is extremely important in interpretation of leaf analyses for the commercial apple grower.

\section{Literature cited}

Autio, W.R. and F.W. Southwick. 1986. The effects of rootstock and root-interstem combination on the growth, productivity, and anchorage of a spur and standard strain Delicious apple tree. Fruit Var. J. 40(4):128-133.

Autio, W.R. and F.W. Southwick. 1993. Evaluation of spur and standard strains of 'McIntosh' on three rootstocks and one dwarfing interstem over ten years. Fruit Var. J. 47(2):95-102.

Autio, W.R., J.A. Barden, and G.R. Brown. 1991. Rootstock affects ripening, size, mineral composition, and storability 'Starkspur Supreme Delicious' in the 1980-81 NC-140 cooperative planting. Fruit Var. J. 45:247-251. 
Awad, M.M. and A.L. Kenworthy. 1963. Clonal rootstock, scion variety and time of sampling influences in apple leaf composition. Proc. Amer. Soc. Hort. Sci. 83:68-73.

Barden, J.A. and D.C. Ferree. 1979. Rootstock dose not affect net photosynthesis, dark respiration, specific leaf weight, transpiration of apple leaves. J. Amer. Soc. Hort. Sci. 104:526-528.

Bartram, R.D., W. Bramlage, E.M. Kupferman, K.L. Olsen, M.E. Patterson, and J. Thompson. 1993. Apple maturity program handbook. USDA-ARS Tree Fruit Res. Sta., Wenatchee, Wash.

Baugher, T.A., S. Singha, D.W. Leach, and S.P. Walter. 1994. Growth, productivity, spur quality, light transmission and net photosynthesis of 'Golden Delicious' apple trees on four rootstocks in three training systems. Fruit Var. J. 48:251255

Bould, C. and A.L. Campbell. 1970. Virus, fertilizer and rootstock effects on the nutrition of young apple trees. J.Amer. Soc. Hort. Sci. 45:287294

Chaplin, M.H. and A.R. Dixon. 1974. A method for analysis of plant tissue by direct reading spark emission spectroscopy. Applied Spectroscopy $28: 5-8$

Chun, I.J., E. Fallahi, B. Shafii, R.R. Tripepi, and W.M. Colt. 2001. Influence of rootstocks and microsprinkler fertigation on photosynthesis of 'Fuji' apple trees. J. Amer. Pomol. Soc. 55(3):(in press).

Drake, S.R., F.E. Larson, J.K. Fellman, and S.S. Higgins. 1988. Maturity, storage quality, carbohydrate, and mineral content of 'Golden spur' apples as influenced by rootstock. J. Amer. Soc. Hort. Sci. 113:949-952.

Dzamic, M., M. Jovanovic, and R. Dzamic. 1980. Distribution of some elements in leaves and fruits of 'Golden Delicious' grown on different rootstocks under the same nutritional conditions, p. 218. In: D. Atkinson, J. E. Jackson, R.O. Sharples, and W.M. Waller (eds.). Mineral nutrition of fruit trees. Butterworths, London.

Eaton, G.W. and M.A. Robinson. 1977. Interstock effects upon apple leaf and fruit mineral content. Can. J. Plant Sci. 57:227-234.

Fallahi, E., M.N. Westwood, M.H. Chaplin, and D.G. Richardson. 1984. Influence of apple rootstocks and $\mathrm{K}$ and $\mathrm{N}$ fertilizers on leaf mineral composition and yield. J. Plant Nutr. 7(8):11611177.

Fallahi, E., D.G. Richardson, and M.N. Westwood. 1985a. Quality of apple fruit from a high-density orchard as influenced by rootstocks, fertilizers, maturity, and storage. J. Amer Soc. Hort. Sci. 110(1):71-74.

Fallahi, E., D.G. Richardson, and M.N. Westwood. 1985b. Influence of rootstocks and fertilizers on ethylene in apple fruit during maturation and storage. J. Amer. Soc. Hort. Sci. 110(2):149-153.

Fallahi, E. and B.R. Simons. 1993a. Effects of rootstocks and thinning on yield, fruit quality, and elemental composition of 'Redspur Delicious' apple. Commun. Soil Sci. Plant Anal. 24(7\&8):589-601.

Fallahi, E. and B.R. Simons. 1993b. Influence of fruit spacing on fruit quality and mineral partitioning of 'Red chief Delicious' apple under full crop conditions. Fruit Var. J. 47:172-178.

Fallahi, E., S.L. Hafez, W.M. Colt, and M.M Seyedbagheri.1998. Effects of metam sodium and rootstock on plant-parasitic nematodes, tree growth, yield, fruit quality, and leaf minerals in 'Braeburn' apple. Nematropica 28(1):71-79.

Fallahi, E. and S.K. Mohan. 2000. Influence of nitrogen and rootstock on tree growth, precocity, leaf mineral nutrients, and fire blight in 'Scarlet Gala' apple. HortTechnology. 10(3):589_ 892.

Fallahi, E., I.J. Chun, G.H. Neilsen, and W.M. Colt. 2001. Effects of three rootstocks on photosynthesis, leaf mineral nutrition, and vegetative growth of 'BC2-Fuji' apple trees. J. Plant Nutr. 24(6):827-834

Ferree, D.C. 1992. Performance of 'Golden Delicious' on two rootstocks and four dwarfing interstems over 10 years. Fruit Var. J. 46(2):9397.

Ferree, M.E. and J.A. Barden. 1971. The influence of strains and rootstocks on photosynthesis, respiration, and morphology of 'Delicious' apple trees. J. Amer. Soc. Hort. Sci. 96:453-457.

Hall, F.H. 1915. Dwarf apples not commercially promising. N.Y. Agr. Expt. Sta. (Geneva) Bul. 406.

Hoblyn, T.N. 1940-41. Manurial trials with apple trees at East Malling, 1920-1939. J. Pomol. Hort. Sci. 18:325-343.

Jones, B.J. 1977. Elemental Analysis of soil extracts and plant tissue ash by plasma emission spectroscopy. Commun. Soil Sci. Plant Anal. 8:349-365.

Jones, O.P. 1971. Effects of rootstocks and interstocks on the xylem sap composition in apples trees: Effects of nitrogen, phosphorus and potassium content. Ann. Bot. 35:825-836.

Kelsall,A. 1946. Some apple stocks at the Kentville station. Annu. Rpt. Nova Scotia Fruit Growers's Assn. 51-55.

Kennedy, A.J., R.W. Rowe, and T.J. Samuelson. 1980. The effects of apple rootstock genotypes on mineral content of scion leaves. Euphytica 29:477-482.

Lockard, R.G. 1976. Effects of apple rootstocks and length and type of interstock on leaf nutrient levels. J. Hort. Sci. 51:289-296.

Meheriuk, M., H.A. Quamme, and R.T. Brownlee. 1994. Influence of rootstock on fruit and tree characteristics of 'Macspur McIntosh'. Fruit Var. J. 48(2):93-97.

Nagai, K. and G. Ishii. 1979. Effect of rootstock and scion cultivars on the mineral composition of apple leaves. Bul. Fruit Tree Res. Sta., Morioka, Iwate, Japan, Ser. C No. 6., p. 84-91.
NC-140 Regional Rootstock Research Project. 1990. Early performance of 'Starkspur Supreme Delicious' on 16 rootstocks in the NC-140 Cooperative Planting. Fruit Var. J. 45:225-235.

NC-140 Regional Rootstock Research Project. 1991. Performance of 'Starkspur Supreme Delicious' apple on 9 rootstocks over 10 years in the NC-140 Cooperative Planting. Fruit Var. J. 45:192-199.

NC-140 Regional Rootstock Research Project. 1996. Rootstock and scion cultivar interact to affect tree performance: A five-year summary of the 1990 NC-140 cultivar/rootstock trial. Fruit Var. J. 50(3):175-187.

Norton, R. 1970. High density apple planting using clonal rootstocks. N.Y. State Hort. Soc. Nwslt. 26(3):1-16.

Rom, C.R., R.C. Rom, W.R. Autio, D.C. Elfving, and R.A. Cline. 1991. Foliar nutrient content of 'Starkspur Supreme Delicious' on nine clonal apple rootstocks. Fruit Var. J. 45:252-263.

Rom, R.C. and R.F. Carlson (eds). 1987. Rootstocks for fruit crops. Wiley, New York.

Schechter, I., D.C. Elfving, and J.T.A. Proctor. 1991. Canopy development, photosynthesis, and vegetative growth as affected by apple rootstocks. Fruit Var. J. 45:229-237.

Schuman, G.E., A.M. Stanley, and D. Knudsen. 1973. Automated total nitrogen analysis of soil and plant samples. Proc. Soil Sci. Soc. Amer. $37: 480-481$.

Sistrunk, J.W. and R.W. Campbell. 1966. Calcium content differences in various apple cultivars as affected by rootstock. Proc. Amer. Soc. Hort. Sci. 88:38-40.

Stiles, W.C. 1994. Nitrogen management in the orchard, p. 41-49. In: A.B. Peterson and R.G. Stevens (eds.). Fruit tree nutrition. Good Fruit Grower, Yakima, Wash.

Tsuchiya, S., Y. Yoshio, T. Haniuda, and T. Sanada. 1974. Twelve years' results on growth, cropping, and fruit quality with three varieties on M.9, M.prunifolia, and apple seedling rootstocks. Bul. Fruit Tree Res. Sta., Morioka, Iwate, Japan, Ser. C No. 1, p. 15-40.

Tsuchiya, S., Y. Yoshida, T. Haniuda, T. Sanada, and S. Sadamori. 1976. The influence of Malling and Malling Merton rootstocks on growth, cropping, and fruit quality of several apple varieties. Bul. Fruit Tree Res. Sta., Morioka, Iwate, Japan, Ser. C No. 3, p. 7-47.

Tukey, H.B. 1964. The historical background of dwarfed fruit trees, p. 11-31. In: Dwarfed fruit trees. Macmillan, New York.

Tukey, R.B., R. Langston, and R.A. Cline. 1962. Influence of rootstock, body stock, and interstock on the nutrient content of apple foliage. Proc. Amer. Soc. Hort. Sci. 80:73-78.

Whitfield, A.B. 1963. The effects of stock and scion on the mineral composition of apple leaves. Ann. Rpt. E. Malling Res. Sta. 107-109. 